\title{
Introduction: The Archaeological Imagination
}

\author{
Alexandra Warwick and Martin Willis
}

\begin{abstract}
Archaeology is the latest born of the sciences. It has but scarcely struggled into freedom, out of the swaddling clothes of dilettante speculations. It is still attracted by pretty things, rather than by real knowledge. It has to find shelter with the Fine Arts or with History, and not a single home has yet been provided for its real growth.
\end{abstract}

\section{(William Mathew Flinders Petrie, Methods and Aims in Archaeology vii)}

What can be called the archaeological imagination long precedes archaeology as a practice. Although histories of archaeology like to mark particular moments as the birth of the science, all acknowledge that those moments are preceded by the existence and even the practice of an archaeological imagination (Daniel). For example, many cite the temple of Larsa in what is now Iraq, which contains a stone inscription recording the work of the ruler Nabonidus (556-539 BC) who, curious about the ruin, caused it to be excavated and restored and attempted to establish something like a history of its construction and use (Schnapp 18). Despite the prior existence of what might be called an archaeological curiosity or wonder, the science of archaeology is deeply marked by the conditions of its emergence in the nineteenth century. As Julian Thomas has pointed out, the science is creatively shaped by its contemporary cultural and linguistic resources, and the nineteenth century presents a particularly dense set of such interactions (Thomas 153). What this reveals, as Flinders Petrie recognised in 1904 in the above epigraph, is that the archaeological imagination is not contained by its professionalization or its own institutions. And likewise, the archaeologist is not untouched by that which the profession often tries to resist: Howard Carter's reply in 1922 when he was asked what he could see through the tiny gap in the door of Tutankhamen's tomb was not "convincing evidence of the funerary practices of the eighteenth dynasty" but "wonderful things" (Silverberg 89).

What is the archaeological imagination? As the writers of the six articles that follow reveal, there are numerous different kinds of imagining taking place in the widest of engagements with archaeology, and these are the product of varied imaginations. Certainly there is no clear division between the professional and rational on the one hand and the creative and imaginative on the other. Rather, explanation and interpretation are as often a part of imaginative responses to archaeology as is the wonder expressed by Carter or indeed by artists or writers of fiction and poetry. At the same time, various imaginative responses to archaeology (whether curatorial, literary, or visual) are employed to extend the explanatory, or rather are brought to bear when the empirical knowledge of scientific archaeology is felt to be unable to capture the entirety of the archaeological experience. In this way, different imaginations offer an argument about the limitations of certain kinds of rational explanation and in doing so lay claim to other truths of archaeological discovery.

As Sophie Thomas reveals, and Mirjam Brusius confirms, archaeological objects (such as those discovered by the adventurer Belzoni or by Layard) retained their status as wondrous and sublime objects when their scientific demarcation was 
unknown (often because a science of archaeology was still in its infancy). Without an explanatory framework the archaeological object was understood within an already existing cultural imaginary: in this instance the paradigms of literary romanticism. Yet, even after the emergence of scientific archaeology imaginative responses to new discoveries were still a necessary component of the archaeological legacy. In particular, as both Shawn Malley and Alex Warwick argue, museums became a locus for the interweaving of the creative with the curatorial. In spaces of exhibition the imagination and the empirical both contributed to archaeological culture: by inviting the viewer to enter the imaginative space of the dream or by evoking an image of Britain that is little more than an imagined nationalism.

Indeed for Malley, as well as for Debbie Challis, Victorian archaeology inspired an imaginative refashioning of Britain and Britishness. In the Victorian imagination 'the East' was always exotic, often in an explicitly Orientalist schema, and the relationship between the originating sites of archaeological objects and their place within British curatorial spaces (the museum, but also the theatre), said as much about Britain as it did about Assyria or Egypt. Both the curated object, and also various poetries written in contemplation of it, very often safeguarded archaeological spaces within a specifically British cultural heritage, suggesting British survival and even progress against Eastern decline and entropy. Malley argues that this was testament to the Victorians' desire to exhibit not archaeological objects but themselves. Challis's reading of the use of ancient Greek dress in both theatrical presentations and in campaigns for national health certainly reinforces this view. Moreover, Challis shows how Greek costume - visualised from empirical archaeological evidence - allowed for a fresh imagining of the British 'body' in various forms: the sexualised body of Victorian women, the healthy body, and the metonymic body of the nation itself.

While the mixing of a curatorial, poetic and artistic imagination spoke to contemporary Britishness rather than to archaeological objects and their former cultural lives, other literary responses offered a differently imagined sense of time and its disjunctions. Virginia Zimmerman notes how imaginative verse often employs archaeology to comment on the complex relationships between the past and the present. She argues that unlike archaeological work itself, poetries of archaeology are able to display both the connections and fractures between the archaeological past and their own contemporary world. The poetic imagination, by compressing time in these ways, strikes out also into the future to ask questions of the meanings of archaeological discoveries for periods yet to come. It is the power of the poetic imagination, then, that enables archaeology to offer fresh insights into time's extended continuum rather than being limited to an understanding of the past alone.

Other imaginative constructions of archaeology work similarly to activate the relationship between the past and present. The visual imagination, in particular, often explores the relationship between the viewer and the archaeological sites and objects upon which they look. To see the materials uncovered by field archaeology is often a precursor to imagining them as active and alive in the present, both as human and non-human actors in the viewer's own culture. As Warwick notes, imperial gothic fictions often bring to life the mummified bodies of ancient cultures or endow the material objects of such cultures with supernatural power. Likewise travel writers such as Amelia Edwards or adventurers like Belzoni (as Thomas discusses) find themselves actively imagining the coming to life of statuary or figures depicted in wall paintings. (Willis 115-41) Such imagining of the reinvigorated life of 
archaeological objects brings them into direct contact with the Victorian present while also transporting the viewer (or reader) into an imaginatively reconstructed past.

Nearly all these examples of an archaeological imagination can be regarded as positive contributions to the legacy of archaeology: all of them, in different ways, extend archaeology's influence into other spheres of social, political and cultural life. Yet the imagination is not always so generous in making plain archaeological knowledge; it can also obscure or disguise important (but largely negative) social and political consequences, or construct a consciously artificial archaeological culture for specific ends. The latter is neatly exemplified by Brusius's detailed discussion of the role of objects, engravings, photographs and museum display in recording and archiving archaeological finds. While it may be expected that the various technologies of image-making capture a material reality objectively (and in the case of the photograph without the conscious and subjective intervention of the artist or sketcher) in actual fact the processes of recording objects are just as often subject to ideological or cultural manipulation. As Brusius argues in her analysis of objects and images sent to the British Museum from Layard's excavations at Nineveh, archaeological images and the display of these images alongside objects in the museum were imaginatively constructed. Their meanings remained multiple, and their status questionable. Rather than delimiting truths about archaeological objects, such images added to the plurality and instability of archaeological knowledge. This, of course, was also true for the photograph of archaeological objects: the apparently objective image captured by the camera was not only as subject to imaginative reconstruction as the artist's sketch, it also disguised that fact by promoting itself as a neutral image-maker that could be relied upon as a source of empirical authority.

The imagination succeeded in supporting other elisions of archaeological truth. Warwick reveals how dream visions of archaeological objects and sites - in poetry, popular fiction and public exhibition - entirely obscures the labour of archaeological field work and writes out the involvement of multiple communities (both Eastern and Western). While this clearly says something about archaeology as an imperial project, Warwick stresses the fact that what is actually hidden by the imagination is the powerful role played by capitalist modernity. The imagination, in this context, worryingly depoliticises both the science of archaeology and its multiple social influences.

When, at the beginning of the twentieth century, Flinders Petrie lamented the fact that archaeology had found "not a single home" in which to flourish, he was speaking specifically about a home for scientific archaeology within a strong disciplinary institution. Considering his contribution to archaeology's extended influence it would be surprising if he did not also recognise that the archaeological imagination had multiple homes in diverse areas of social and cultural life. It is recent scholarship that has begun to recognise that such diversity is not a sideshow to the important work of scientific archaeology but works rather to enlarge the continuum of archaeological knowledge. As the articles in this special issue attest, the meanings of archaeology are enhanced by the different imaginations brought to bear on its sites and objects. Poetry and fiction, museum and commercial exhibits and shows, popular technologies, diaries and travel narratives, dramatic theatre and art all imagine archaeology differently, yet all contribute to the powerful role it plays both within and outside its specific scientific communities. Their imaginative visions of archaeology offer means of additional interpretation and find new, creative truths yet they also provide a means of escaping or hiding from archaeology's more ambiguous roles in Victorian social and cultural politics. What the following articles reveal, then, is that 
the archaeological imagination is plural and constitutive of new knowledge but equally has the capacity to elide or disguise such knowledge: enhancing fact with fancy, but also relieving fact of its discomfort. 


\section{Works Cited}

Daniel, Glyn. 150 Years of Archaeology. London: Duckworth, 1978.

Petrie, William Matthew Flinders. Methods and Aims in Archaeology. New York:

Macmillan, 1904.

Schnapp, Alain. The Discovery of the Past. Trans. Ian Kinnes and Gillian Varndell. London: British Museum Press, 1996.

Silverberg, Robert. Great Adventures in Archaeology. Lincoln: University of Nebraska Press, 1997.

Willis, Martin. Vision, Science and Literature, 1870-1920: Ocular Horizons. London: Pickering and Chatto, 2011. 